\title{
Prevalence, Species Differentiation, Haemolytic Activity, and Antibiotic Susceptibility of Aeromonads in Untreated Well Water
}

\author{
Khalifa Sifaw Ghenghesh $/{ }^{+}$, Abdelmula El-Ghodban*, Rabia Dkakni, \\ Salaheddin Abeid, Abdurazzaq Altomi, Abdussalam Tarhuni**, \\ Karoly Marialigeti*
}

\begin{abstract}
Department of Medical Microbiology, Faculty of Medicine, P.O. Box 80013, Tripoli, Libya *Faculty of Science, Eotvos Lorand University, Budapest, Hungary **Arab Company of Soft Drinks and Mineral Water, Tripoli, Libya
\end{abstract}

The use of untreated water for drinking and other activities have been associated with intestinal and extraintestinal infections in humans due to Aeromonas species. In the present study aeromonads were isolated from $48.7 \%$ of 1,000 water samples obtained from wells and other miscellaneous sources. Aeromonas species were detected in $45 \%$ of samples tested in spring, $34.5 \%$ in summer, $48 \%$ in autumn and $60 \%$ of samples tested in winter. Speciation of 382 strains resulted in 225(59\%) being A. hydrophila, $103(27 \%)$ A. caviae, $42(11 \%)$ A. sobria and 11 (3\%) atypical aeromonads. Of 171 Aeromonas strains tested for their haemolytic activity, 53\%, 49\%, 40\% and 37\% were positive in this assay using human, horse, sheep and camel erythrocytes respectively. The results obtained indicate that potentially enteropathogenic Aeromonas species are commonly present in untreated drinking water obtained from wells in Libya (this may also apply to other neighbouring countries) which may pose a health problem to users of such water supplies. In addition, ceftriaxone and ciprofloxacin are suitable drugs that can be used in the treatment of Aeromonas-associated infections, particularly in the immunocompromised, resulting from contact with untreated sources of water.

Key words: Aeromonas - water - haemolysin - erythrocytes - antibiotics

Members of the genus Aeromonas are gramnegative, oxidase-positive, facultative anaerobic, rod-shaped bacteria of the family Vibrionaceae. They occur naturally in fresh water sources and are established pathogens of fish and amphibians (Hazen et al. 1978, Hazen \& Fleirmans 1979, Buchanan \& Palumbo 1985). In humans, aeromonads have for some time been recognized as opportunistic pathogens in the immunocompromised (von Graevenitz \& Mensch 1968, Washington 1972). They have been isolated from skin and soft tissue infections of patients without underlying conditions, but who suffered a trauma followed by exposure to water (Gold \& Salit 1993). Furthermore, Aeromonas species have been implicated as causative agents of diarrhoea in children and adults (Burke et al. 1983a, Goodwin et

${ }^{+}$Corresponding author. Fax: 218-21-333.4474. E-mail: Ghenghesh_micro@yahoo.com

Received 28 March 2000

Accepted 15 August 2000 al. 1983, Janda et al. 1983, George et al. 1985, SanJoaquin \& Picket 1988). Several studies have reported that the drinking of untreated water is the most probable manner of acquiring these organisms (Holmberg et al. 1986, Moyer 1987). At least 13 species are included in the genus Aeromonas at this time (Janda 1991). Three of these, namely hydrophila, caviae and sobria, are most commonly associated with disease in humans. A number of virulence factors have been associated with these organisms and may be responsible for their enteropathogenicity, these include the production of cytotoxins, enterotoxins and haemolysins (Gracey et al. 1982, Singh \& Sanyal 1992, Majeed \& Macrae 1994). Burke et al. (1983b) have shown that haemolytic aeromonads are also enterotoxigenic and suggested that the detection of the haemolytic activity is sufficient to discriminate enterotoxigenic Aeromonas species. Although, Aeromonasassociated disease in the very young, the old and the immunocompromised often requires antimicrobial therapy, reports on the susceptibility of these organisms to antimicrobial agent are rare in our region. Furthermore, information concerning species distribution of aeromonads in well water is lacking. The present study was carried out to determine the 
prevalence, species differentiation, haemolytic activity (using four different types of erythrocytes), and antibiotic susceptibility of Aeromonas strains in untreated well water in Tripoli area (population 1.5 millions).

\section{MATERIALS AND METHODS}

\section{Water samples}

From March, 1993 to December, 1994, 1,000 drinking water samples obtained from wells $(98 \%$ of samples) and other miscellaneous sources of untreated water were examined. Water samples were collected in sterile containers and processed within $3 \mathrm{~h}$ of collection. When it was known, the depth of each well was recorded.

\section{Bacteriology}

Isolation - For the isolation of aeromonads, 2.5 $\mathrm{ml}$ of the water samples were added to $25 \mathrm{ml}$ of alkaline peptone water (APW, $\mathrm{pH}$ 8.6) for enrichment. After an overnight incubation at $37^{\circ} \mathrm{C}$, a loopful from the APW was plated onto blood agar supplemented with $15 \mathrm{mg} / \mathrm{l}$ ampicillin and the plates were incubated at $37^{\circ} \mathrm{C}$ overnight.

Identification - Identification of Aeromonas species was carried out using API 20E System (BioMerieux, France) and the following tests: production of oxidase, resistance to agent $\mathrm{O} / 129$ (Oxoid, UK), gas production from glucose and aesculin hydrolysis. Isolates identified as Aeromonas by the API 20E, and which did not produce gas from glucose nor hydrolyse aesculin were considered as atypical aeromonads.

Haemolysin assay - Bacterial strains were inoculated into $10 \mathrm{ml}$ of brain heart infusion broth supplemented with $0.3 \%(\mathrm{wt} / \mathrm{vol})$ yeast extract (Oxoid), and incubated at $37^{\circ} \mathrm{C}$ with agitation (200 rpm) in a waterbath shaker (Karl Kolb, West Germany) for $48 \mathrm{~h}$. Cell-free supernatants were prepared by centrifugation $(4000 \times \mathrm{g}, 30 \mathrm{~min})$ at $4^{\circ} \mathrm{C}$ and filtration $(0.45 \mu \mathrm{m}$ membrane filters, Sartorius, West Germany). Doubling dilutions of the cell-free supernatant test solutions in phosphate buffered saline $(\mathrm{pH} 7.4)$ were made in microtiter trays. Equal volumes $(100 \mu \mathrm{l})$ of a $1 \%$ suspension of fresh, washed (three times) human, horse, sheep or camel erythrocytes was added. Phosphate buffered saline and broth blanks were included in each tray. Trays were sealed and incubated for $1 \mathrm{~h}$ at $37^{\circ} \mathrm{C}$ and then for $1 \mathrm{~h}$ at $4^{\circ} \mathrm{C}$. Haemolytic activity of cell-free supernatants was considered positive if dilutions of $>1: 4$ of each supernatant yielded $50 \%$ haemolysis of the erythrocytes. A total 171 Aeromonas strains was tested in this assay.

Antibiotic susceptibility tests - The susceptibility of 40 Aeromonas strains to antimicrobial agent was determined by the disc diffusion method
(Bauer et al. 1966). The following antibiotics were tested (Oxoid, UK): ampicillin, ceftriaxone, ciprofloxacin, cephaloridine, chloramphenicol, gentamicin, kanamycin, nalidixic acid, tetracycline and trimethoprim-sulpha-methoxazole.

\section{RESULTS}

Aeromonas species were isolated from 487 (48.7\%) water samples. Speciation of 382 strains resulted in 59\% being A. hydrophila, 27\% A. caviae, $11 \%$ A. sobria and $3 \%$ atypical aeromonads (Table I). Information on the depth of 481 wells was available. The wells were divided into three groups according to their depth and aeromonads were isolated form $56 \%$ of 178 wells less than $20 \mathrm{~m}, 53 \%$ of 238 wells $20-30 \mathrm{~m}$ and $49 \%$ of 65 wells more than $30 \mathrm{~m}$ deep. The isolation rates of Aeromonas species from the three groups of wells are not statistically significant $(\mathrm{P}>0.05)$. Aeromonads were detected in $45 \%$ of samples tested in spring, $34.5 \%$ in summer, $48 \%$ in autumn and $60 \%$ of samples tested in winter (Table II). Haemolytic activity of 171 Aeromonas strains tested against human, horse, sheep and camel erythrocytes is shown in Table III. Regardless of the erythrocytes used, the results obtained show a statistically significant difference between haemolysin production with $A$. sobria and $A$. hydrophila compared with A. caviae strains ( $\mathrm{P}<0.001$, Chi-square test). Susceptibility testing of 40 Aeromonas strains (24 A. hydrophila, 12 A. caviae and $4 A$. sobria) against antimicrobial agents resulted in $100 \%$ being resistant to ampicillin, $95 \%$ to cephaloridine, and 5\% to tetracycline. All (100\%)

\section{TABLE I}

Results of speciation of 381 Aeromonas strains isolated from untreated water

\begin{tabular}{lc}
\hline Species & No. $(\%)$ isolated \\
\hline A. hydrophila & $225(59)$ \\
A. caviae & $103(27)$ \\
A. sobria & $42(11)$ \\
Atypical aeromonads & $11(3)$ \\
\hline Total tested & $381(100)$ \\
\hline
\end{tabular}

TABLE II

Seasonal distribution of Aeromonas species isolated from untreated water

\begin{tabular}{lcc}
\hline Season & No. tested & No. $(\%)$ isolated \\
\hline Spring & 60 & $27(45)$ \\
Summer & 284 & $98(34.5)$ \\
Autumn & 313 & $150(48)$ \\
Winter & 343 & $205(60)$ \\
\hline
\end{tabular}


TABLE III

Haemolytic activity of Aeromonas species isolated from well water in Tripoli area

\begin{tabular}{lcccc}
\hline & \multicolumn{4}{c}{$\%$ of Aeromonas species showing haemolysis } \\
\cline { 2 - 5 } Erythrocytes used & hydrophila $(n=52)$ & caviae $(n=93)$ & sobria $(n=26)$ & Total $(n=170)$ \\
\hline Human & 67 & 34 & 88 & 53 \\
Horse & 62 & 30 & 88 & 49 \\
Sheep & 52 & 25 & 73 & 40 \\
Camel & 52 & 22 & 65 & 37 \\
Mean value $^{a}$ & 58 & 28 & 79 & 45 \\
\hline
\end{tabular}

$a$ : mean value for the sum of all assays

strains were susceptible to ceftriaxone, ciprofloxacin, chloramphenicol, gentamicin, kanamycin, nalidixic acid and trimethoprimsulphamethoxazole.

\section{DISCUSSION}

In the present study, nearly $50 \%$ of the untreated water samples examined were positive for Aeromonas species and nearly all of these samples were obtained from wells. In a study, on the role of Aeromonas species in intestinal infections in the United States, Holmberg et al. (1986) reported that, of 20 patients who could specify their water supply in the week before their gastrointestinal illness, 18 had obtained their water from private wells and two had been drinking untreated spring water.

Aeromonas species were reported to be isolated in higher numbers during the summer (Ljungh \& Wadstrom 1985). Also Aeromonas-associated diarrhoea was found to be high during the summer months (Burke et al. 1984, Agger et al. 1985). In the present work, isolation rates of aeromonads were highest in the months of winter and lowest in summer. Although there is no clear explanation to our findings, we can speculate this is may be due to the relatively mild winter and hot summer seasons in our region. Pathak et al. (1988), studying the seasonal distribution of aeromonads in river water, reported similar findings.

We found no differences in the isolation rates of Aeromonas species in the water samples obtained from wells with different depths. However, it is worth mentioning that one strain (A. caviae) was isolated from a water sample obtained from a well of $106 \mathrm{~m}$ deep.

There is little information available about species distribution in aquatic environment (Araujo Boira 1996). In the present study, A. hydrophila was the most common species representing nearly $60 \%$ of the aeromonads identified to the species level. These results are consistent with the findings of others (Krovacek et al. 1992, Hanninen et al. 1997, Kuhn et al. 1997) who reported that A. hydrophila is the predominant species in freshwater and municipal drinking water supplies.

Using tissue culture and horse erythrocytes, a statistically significant correlation between production of cytotoxic haemolysin and the presence of diarrhoea has been reported by Brauer et al. (1985). Although in the present study the cytotoxic activity of the Aeromonas strains was not determined, the results obtained show that nearly half of our isolates were haemolytic and therefore may be enteropathogenic.

Erythrocytes from small laboratory animals (mouse, rabbit, guinea pig) have been reported to be more sensitive than human and sheep erythrocytes in the Aeromonas haemolysis assay (Handfield et al. 1996). However, if the haemolysin assay is to be used routinely in clinical laboratories to detect enteropathogenic aeromonads, small animals are not a practical source of erythrocytes to be used in such an assay. Our findings and those of others (Monfort \& Baleux 1991) support the use of human or horse erythrocytes in the haemolysin assay and show that this simple assay can be easily used to assist in the detection of pathogenic strains of Aeromonas species isolated from untreated water sources. Although camel erythrocytes have not been reported previously to detect haemolytic aeromonads, they are not recommended for use in Aeromonas haemolysis assay.

In addition to drinking untreated water that contains Aeromonas species, the taking of antibiotics such as ampicillin to which these organisms are resistant, may be a predisposing factor for the development of gastroenteritis (Holmberg et al. 1986, Moyer 1987). Antibiotic-resistant strains of Aeromonas have been isolated from aquatic environments and this resistance is principally plasmid mediated (Hedges et al. 1985, Borrego et al. 1991). Similar to other reports (Altwegg \& Geiss 1989) all our isolates were resistant to ampicillin and $95 \%$ to cephaloridine. All were susceptible to ceftriaxone, cholramphenicol, ciprofloxacin and gentamicin. Although the isolates were also susceptible to 
trimethoprim-sulphamethoxazole and nalidixic acid, recently we isolated aeromonads from children with diarrhoea and from chicken carcases that were highly resistant to trimethoprim-sulphamethoxazole and nalidixic acid respectively (Ghenghesh et al. 1998). Because of the isolation of multiple-resistant Aeromonas species (including to trimethoprimsulphamethoxazole and nalidixic acid) from freshwater in other parts of the world (Borrego et al. 1991), our findings warrant the need to take proper measures to prevent the introduction of aeromonads, that are resistant to these drugs, to water sources used by humans.

In Libya, as it is in other developing countries, it is common to use water obtained from wells and other untreated sources, in addition to drinking, for bathing and other purposes and this may be hazardous to individuals with wounds, lacerations or abrasions (Janda \& Duffey 1988, Gold \& Salit 1993, Kelly et al. 1993, Newton \& Kennedy 1993). Patients at risk to infections with Aeromonas species also include those with underlying malignancies and hepatobiliary disease (Goodwin et al. 1983, Rolston et al. 1991).

We conclude that potentially enteropathogenic Aeromonas species are commonly present in untreated drinking water obtained from wells in Libya (this may also apply to other neighbouring countries) which may pose a health problem to users of such water supplies. In addition, ceftriaxone and ciprofloxacin are suitable drugs that can be used in the treatment of Aeromonas-associated infections, particularly in the immunocompromised, resulting from contact with untreated sources of water.

\section{REFERENCES}

Agger WA, McCormick JD, Gurwith MJ 1985. Clinical and micro-biological features of Aeromonas hydrophila associated with diarrhoea. J Clin Microbiol 21: 909-913.

Altwegg M, Geiss HK 1989. Aeromonas as a human pathogen. CRC Critical Rev Microbiol 16: 253-286.

Araujo Boira RM 1996. Hydrophila group aeromonads in environmental waters. Culture 17: 2-4.

Bauer AW, Kirby WMM, Sherris JC, Turch M 1966. Antibiotic susceptibility testing by a standard single disk method. Amer J Clin Pathol 45: 493-496.

Borrego JJ, Morinigo MA, Martinez-Manzanares E, Bosca M, Castro D, Barja JL, Toranzo AE 1991. Plasmid associated virulence properties of environmental isolates of Aeromonas hydrophila. $J$ Med Microbiol 35: 264-269.

Brauer C, Scheftel JM, Rihn B, Monteil H 1985. Isolamente de Aeromonas hydrophila daus les diarrhies: caracterisation des souches enterotoxigenes et relations cliniques. Ann Biol Clin 43: 725-731.

Buchanan RL, Palumbo SA 1985. Aeromonas hydrophila and Aeromonas sobria as potential food poisoning species: a review. J Food Safety 7: 15-29.
Burke V, Gracey M, Robinson J, Peck D, Beaman J, Bundell C 1983a. The microbiology of children gastroenteritis: Aeromonas species and other infective agents. J Infect Dis 148: 68-74.

Burke V, Robinson J, Beaman J, Gracey M, Lesmana M, Rockhill R, Echeverria P, Janda JM 1983b. Correlation of enterotoxicity with biotype in Aeromonas spp. J Clin Microbiol 18: 1196-1200.

Burke V, Robinson J, Gracey M, Peterson D, Patridge K 1984. Isolation of Aeromonas hydrophila from a metropolitan water supply: seasonal correlation with clinical isolates. Appl Environ Microbiol 48: 361366.

George WL, Nakata MM, Thompson J, White ML 1985. Aeromonas related diarrhoea in adults. Arch Intern Med 145: 2207-2211.

Ghenghesh KS, Abeid S, Dkakni R, Tawil A, Elkot R 1998. Susceptibility of Aeromonas species isolated in Libya to antimicrobial agents. Second International Meetings on the Therapy of Infections, Florence, Italy, Abstract A27, p. 124.

Gold WL, Salit IE 1993. Aeromonas hydrophila infections of skin and soft tissue: report of 11 cases and review. Clin Infect Dis 16: 69-70.

Goodwin CS, William ES, Stewart JK, Gracey M, Burke V, Robison J 1983. Enterotoxigenic Aeromonas hydrophila and diarrhoea in adults. Med J Australia 1: 25-26.

Gracey M, Burke V, Robinson J 1982. Aeromonasassociated gastroenteritis. Lancet ii: 1304-1306.

Handfield M, Smard P, Cuillard M, Letarte R 1996. Aeromonas hydrophila isolated from food and drinking water: hemagglutination, hemolysis, and cytotoxicity for a human intestinal cell line (HT-29). Appl Environ Microbiol 62: 3459-3461.

Hanninen ML, Oivanen P, Hirvela-Koski V 1997. Aeromonas species in fish, fish-eggs, shrimp and fresh water. Inter J Food Microbiol 34: 17-26.

Hazen TC, Fleirmans CB 1979. Distribution of Aeromonas hydrophila in natural and man-made thermal effluents. Appl Environ Microbiol 38: 166168.

Hazen TC, Fleirmans CB, Hirsch RP, Esch GW 1978. Prevalence and distribution of Aeromonas hydrophila in the United States. Appl Environ Microbiol 36: 731-738.

Hedges RW, Smith P, Brazil G 1985. Resistance plasmids of aeromonads. J Gen Microbiol 131: 2091-2095.

Holmberg SD, Schell LW, Fanning GR, Wachsmith LK, Hickman-Brenner FW, Blake PA, Brenner DJ, Farmer III JJ 1986. Aeromonas intestinal infections in the United States. Ann Intern Med 105: 683-689.

Janda JM 1991. Recent advances in the study of the taxonomy, pathogenicity, and infection syndromes associated with the genus Aeromonas. Clin Microbiol Rev 4: 397-410.

Janda JM, Duffey PS 1988. Mesophilic aeromonads in human disease: current taxonomy, laboratory identification and infectious disease spectrum. Rev Infect Dis 10: 980-997.

Janda JM, Bottone EJ, Skinner CV, Calcaterra D 1983. Phenotypic markers associated with gastrointestinal Aeromonas hydrophila isolates from symptomatic 
children. J Clin Microbiol 17: 588-591.

Kelly KA, Koehler JM, Ashdown LR 1993. Spectrum of extraintestinal disease due to Aeromonas species in tropical Queensland, Australia. Clin Infect Dis 16: 574-579.

Krovacek K, Faris A, Baloda SB, Lindberg T, Peterz M, Mansson I 1992. Isolation and virulence profiles of Aeromonas spp. from different municipal drinking water supplies in Sweden. Food Microbiol 9: 215222.

Kuhn I, Alletam G, Huys G, Janssen P, Kersters K, Krovacek K, Stenstrom T 1997. Diversity, persistance, and virulence of Aeromonas strains isolated from drinking water distribution systems in Sweden. Appl Environ Microbiol 63: 2708-2715.

Ljungh A, Wadstrom T 1985. Aeromonas and Plesiomonas as possible causes of diarrhoea. Infection 13: 169-173.

Majeed KN, Macrae IC 1994. Cytotoxic and haemagglutinating activities of motile Aeromonas species. J Med Microbiol 40: 188-193.

Monfort P, Baleux B 1991. Haemolysin occurrence among Aeromonas hydrophila, Aeromonas caviae and Aeromonas sobria strains isolated from different aquatic ecosystems. Res Microbiol 142: 95-102.

Moyer NP 1987. Clinical significance of Aeromonas species isolated from patients with diarrhoea. J Clin Microbiol 25: 2044-2048.

Newton Jr. JA, Kennedy CA 1993. Wound infection due to Aeromonas sobria. Clin Infect Dis 17: 10821083.

Pathak SP, Bhattacherjee JW, Kalra N, Chandra S 1988. Seasonal distribution of Aeromonas hydrophila in river water and isolation from river fish. $J A p p l$ Bacteriol 65: 347-352.

Rolston KVI, Zandvliet SE, Rodriguez S, Nguyen HT, Bodey GP 1991. Spectrum of Aeromonas and Plesiomonas infections in patients with cancer and Aids. Experientia 47: 437-439.

San-Joaquin VH, Pickett DA 1988. Aeromonasassociated gastroenteritis in children. Paediatric Infect Dis J 7: 53-57.

Singh DV, Sanyal SC 1992. Production of haemolysis and its correlation with enterotoxicity in Aeromonas spp. J Med Microbiol 37: 262-267.

von Graevenitz A, Mensch AH 1968. The genus Aeromonas in human bacteriology: report of 30 cases and review of the literature. N Engl J Med 278: 245249.

Washington JA 1972. Aeromonas hydrophila in clinical bacteriological specimens. Ann Intern Med 76: 611614. 